\title{
molecules
}

ISSN 1420-3049

www.mdpi.com/journal/molecules

Article

\section{Design, Synthesis, Antinociceptive and Anti-inflammatory Activities of Novel Piroxicam Analogues}

Amanda Silva de Miranda ${ }^{1,2}$, Walfrido Bispo Júnior ${ }^{3,4}$, Yolanda Karla Cupertino da Silva ${ }^{3,4}$, Magna Suzana Alexandre-Moreira ${ }^{3,4}$, Rosane de Paula Castro ${ }^{5}$, José Ricardo Sabino ${ }^{5}$, Luciano Morais Lião ${ }^{6}$, Lídia Moreira Lima ${ }^{1,2}$ and Eliezer J. Barreiro ${ }^{1,2, *}$

1 LASSBio ${ }^{\circledR}$ - Laboratório de Avaliação e Síntese de Substâncias Bioativas, Faculdade de Farmácia, Universidade Federal do Rio de Janeiro, P.O. Box 68024, 21944-971, Rio de Janeiro, RJ, Brazil

2 Pós-graduação em Química, Instituto de Química, Universidade Federal do Rio de Janeiro, 21941-909, Rio de Janeiro, RJ, Brazil

3 LaFI - Laboratório de Farmacologia e Imunidade, Instituto de Ciências Biológicas e da Saúde, Universidade Federal de Alagoas, 57072-970, Maceió, AL, Brazil

4 RENORBIO, Rede Nordeste de Biotecnologia, Universidade Federal de Alagoas, 57072-970, Maceió, AL, Brazil

5 Instituto de Física, Universidade Federal de Goiás, 74001-970, Goiânia, GO, Brazil

6 Instituto de Química, Universidade Federal de Goiás, 74001-970, Goiânia, GO, Brazil

* Author to whom correspondence should be addressed; E-Mails: ejbarreiro@ccsdecania.ufrj.br and/or lidia@pharma.ufrj.br; Tel.: +55-2125626478/+55-2125626644.

Received: 6 November 2012; in revised form: 19 November 2012 / Accepted: 20 November 2012 / Published: 28 November 2012

\begin{abstract}
In this paper we report the design, synthesis, antinociceptive and anti-inflammatory activities of a series of benzothiazine $N$-acylhydrazones $14 \mathbf{a}-\mathbf{h}$, planned by structural modification of piroxicam (1), a non steroidal anti-inflammatory drug. Among the synthesized analogues, compounds 14f (LASSBio-1637) and 14g (LASSBio-1639) were identified as novel antinociceptive and anti-inflammatory prototypes, active by oral administration, acting by a mechanism of action that seems to be different from that of piroxicam, since they were inactive as an inhibitor of cyclooxygenase (COX-1 and COX-2) at concentrations of $10 \mu \mathrm{M}$.
\end{abstract}

Keywords: piroxicam; inflammation; pain; acylhydrazone; NSAID; COX 


\section{Introduction}

Inflammation is an adaptive response triggered by trauma, tissue injury or infection, characterized by symptoms such as pain, redness, heat and swelling. Acute inflammation is mediated mainly by the release of prostaglandins and other pro-inflammatory mediators, like leukotrienes, bradykinin and histamine, which promote local vascular alterations and leukocyte recruitment and activation. This process is normally self limited and resolution occurs with elimination of the noxious stimuli, removal of inflammatory cells and tissue repair. However, under certain conditions the inflammatory process persists, leading to a chronic inflammatory process, which additionally involves interleukins, tumor necrosis $\alpha$, interferons, among other mediators, and underlines a variety of chronic diseases, such as cancer, atherosclerosis and reumathoid arthiritis [1-3]. Currently drug management of inflammation includes non steroidal anti-inflammatory drugs (NSAIDs), glucocorticoids, slow-acting disease-modifying anti-rheumatic drugs (DMARDs), immunosuppressants and biologics that specifically target inflammatory cytokines [3].

Piroxicam (4-hydroxy-2-methyl-2H-1,2-benzothiazine-1-( $N$-(2-pyridinyl)carboxamide)-1,1-dioxide), (1) [4] is a NSAID discovered in 1972 and introduced in the market by Pfizer in 1982, being the first drug of the "oxicam" class [5], to which meloxicam (2) [6], tenoxicam (3) [7] and lornoxicam (4) [8] (Figure 1) also belong. Piroxicam is a long half-life drug (45 h in humans) [9] which also possess analgesic and antipyretic properties and has been used in the management of chronic inflammatory diseases [10], such as rheumatoid arthritis and osteoarthritis, for almost 30 years. Like other NSAIDs, the therapeutic effects of piroxicam have been attributed to its ability to inhibit cyclooxygenase (COX), [11,12] a key enzyme in the biosynthesis of pro-inflammatory prostanoids, such as prostaglandins.

Figure 1. Oxicam class drugs.<smiles>CN1C(C(=O)Nc2ccccn2)=C(O)c2ccccc2S1(=O)=O</smiles><smiles>CN1C(C(=O)Nc2nccs2)=C(O)c2ccccc2S1(=O)=O</smiles><smiles>CN1C(C(=O)Nc2ccccn2)=C(O)c2sccc2S1(=O)=O</smiles><smiles>CN1C(C(=O)Nc2ccccn2)=C(O)c2sc(Cl)cc2S1(=O)=O</smiles>

The $\mathrm{N}$-acylhydrazone (NAH; 5) framework has recently been recognized as a privileged structure [13-15] and several NAH derivatives (Figure 2) have been reported with different pharmacological activities, such as PDE inhibitors 6 [16] COX inhibitors 7 [17], TRPV1 antagonists 8 [18], HIV-1 capsid protein assembly inhibitors 9 [19], and CB2 inverse agonists 10 [20], among others. Moreover, many $\mathrm{N}$-acylhydrazones were described by our research group as potent anti-inflammatory and antinociceptive compounds [21], which have been attributed to the NAH framework's ability to mimic amide group and the bis-allylic moiety of unsaturated fatty acids, such as arachidonic acid [22,23]. 
Figure 2. $N$-acylhydrazones derivatives with different activities.

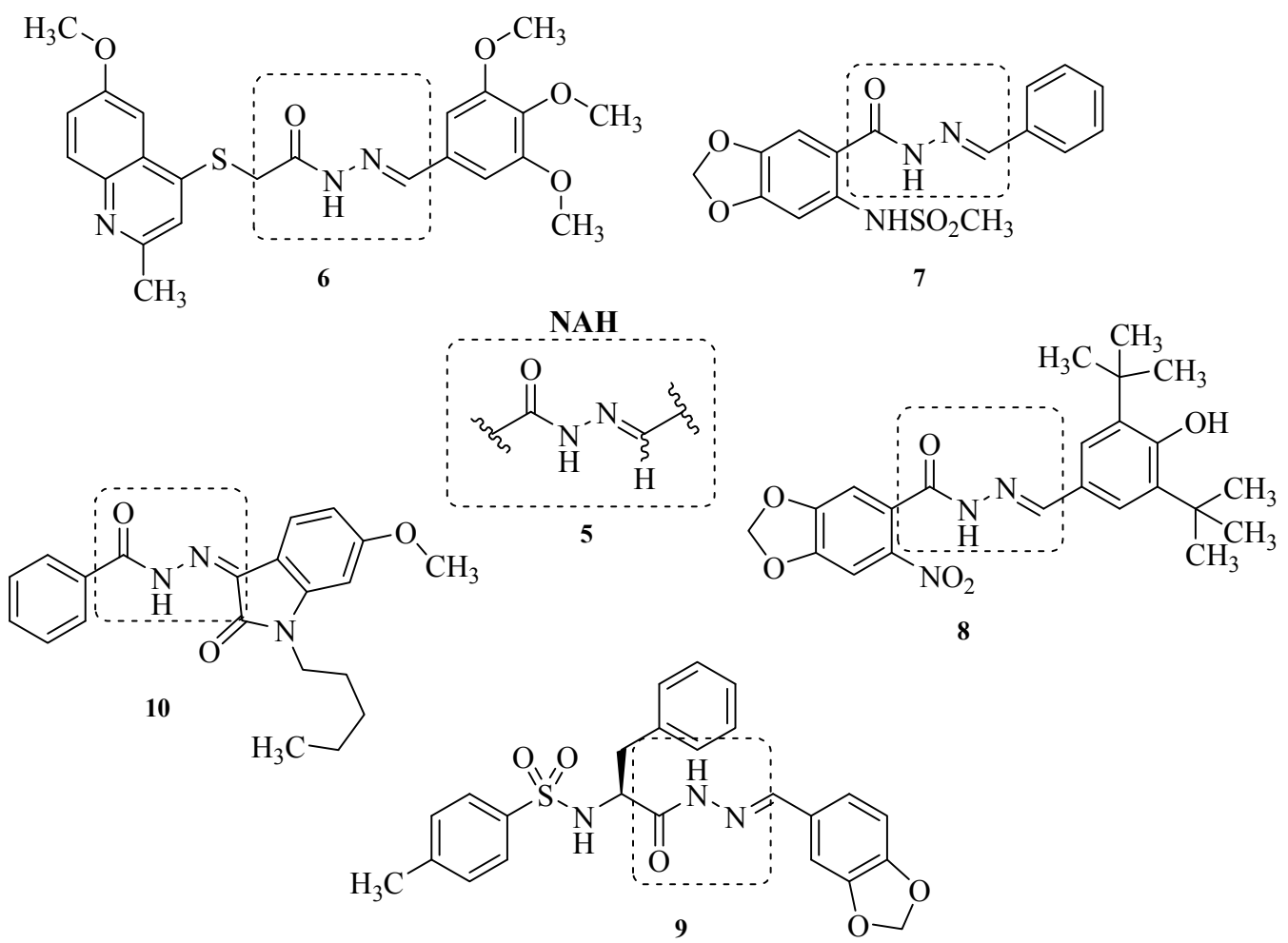

Very recently, some antioxidant and antimicrobial $N$-acylhydrazones bearing a 4-hydroxy-1,2benzothiazine-1,1-dioxide scaffold were reported [24-26] (Figure 3). Nevertheless, to the best of our knowledge, the antinociceptive and anti-inflammatory potential of this molecular pattern has not been investigated. Besides, some structural features that seems to be related to the oxicams' anti-inflammatory activity, such as heteroaromatic amide subunit [4,27], have not been fully explored in these previous works.

Figure 3. Antioxidant and antimicrobial $N$-acylhydrazones bearing a 4-hydroxy-1,2benzothiazine-1,1-dioxide scaffold.<smiles>O=C(N/N=C/c1ccc(Cl)cc1Cl)C1=C(O)c2ccccc2S(=O)(=O)N1</smiles><smiles>C/C(=N\NC(=O)C1=C(O)c2ccccc2S(=O)(=O)N1)c1ccccc1O</smiles><smiles>COc1ccc(/C(C)=N/NC(=O)C2=C(O)c3ccccc3S(=O)(=O)N2C)cc1</smiles>

In this paper, we report the design, synthesis and pharmacological evaluation of a novel series of antinociceptive and anti-inflammatory $\mathrm{N}$-acylhydrazones derivatives (all compounds are original, with the exception of 14a, which was first published by Zia-ur-Rehman et al. [24]). Target compounds 14a-h 
were designed (Figure 4) to include a 4-hydroxy-1,2-benzothiazine-1,1-dioxide scaffold, a pharmacophore present in oxicam drugs, such as pioxicam, and the NAH framework, a privileged structure which is also encountered in many anti-inflammatory compounds [21]. The nature of the aryl and heteroaryl groups attached to the imine subunit was varied based on ring isosteric replacement to give 14a-f. In addition, we have synthesized compound $\mathbf{1 4 g}$, which bears a biphenyl group, a pharmacophore found in some recently reported mPGES-1 inhibitors [28] and also considered a privileged structure $[13,14]$. In order to confer antioxidant and radical scavenging properties we designed compound $\mathbf{1 4 h}$, featuring a 3,5-di-tert-butyl-4-hydroxyphenyl group, a subunit found in many dual cyclooxygenase/5-lipoxygenase (COX/5-LOX) inhibitors [29].

Figure 4. Design of a novel series of analgesic and anti-inflammatory benzothiazine $N$-acylhydrazones.
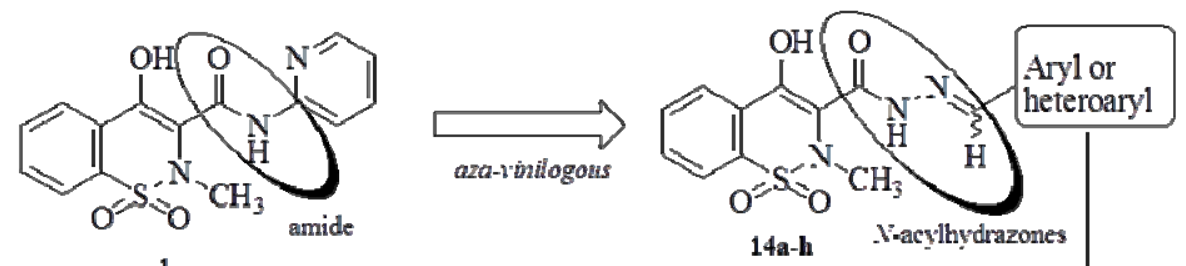

$$
\text { (piroxicam) }
$$

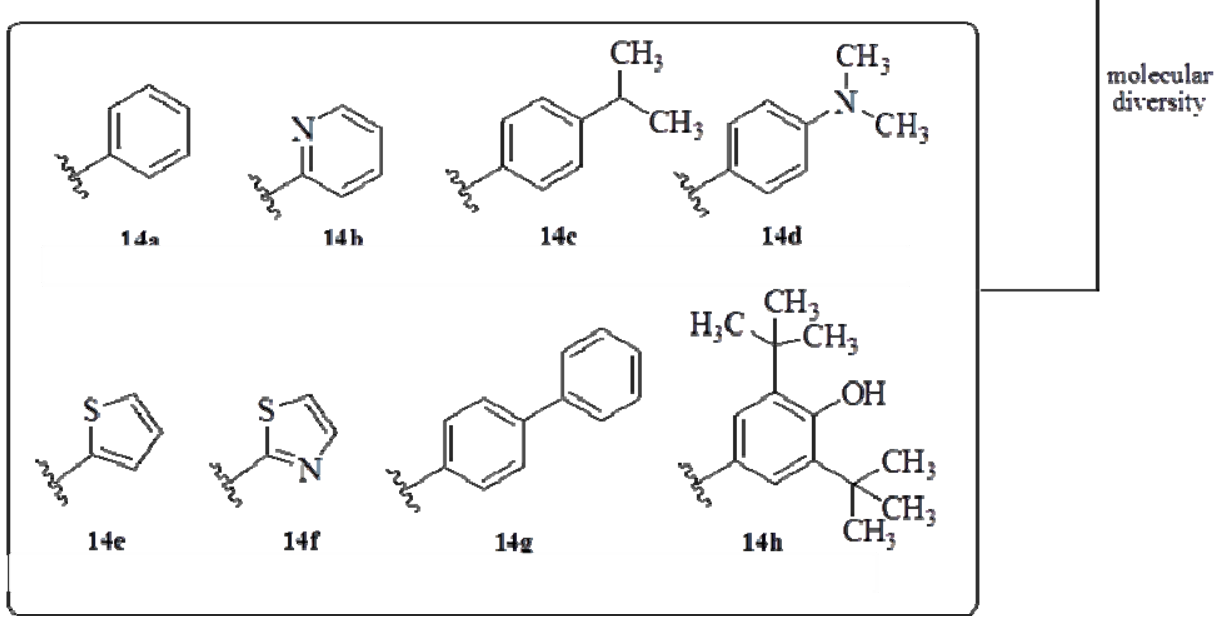

\section{Results and Discussion}

\subsection{Chemistry}

$N$-acylhydrazones 14a-h were synthesized from commercial available ethyl 4-hydroxy- $2 H$-1,2benzothiazine-3-carboxylate 1,1-dioxide [30] (15) in two steps, as depicted in Scheme 1. The key intermediate 16 was obtained in $68 \%$ yield by treating an ethanolic solution of 15 with $98 \%$ hydrazine monohydrate for $2 \mathrm{~h}$ under reflux [31]. Finally, condensation of $\mathbf{1 5}$ with appropriate aromatic and heteroaromatic aldehydes at room temperature, under acid catalysis [31], provided the target compounds $\mathbf{1 4 a}-\mathbf{h}$ in $48-63 \%$ overall yield. 
Scheme 1. Synthesis of compounds 14a-h.

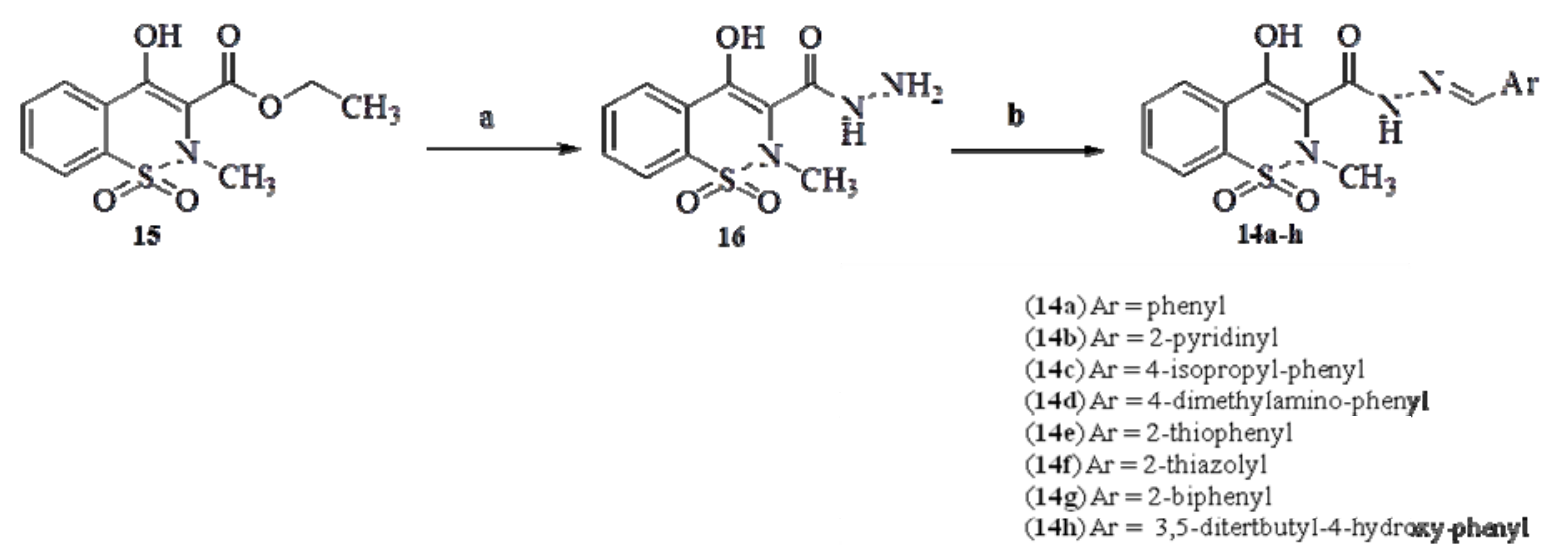

Reagents and conditions: (a) $\mathrm{NH}_{2} \mathrm{NH}_{2} \cdot \mathrm{H}_{2} \mathrm{O} 98 \%$, ethanol, reflux, 2h, 68\%; (b) ArCHO, ethanol, $\mathrm{HCl}$ cat., r.t., $30-50 \mathrm{~min}, 48-63 \%$ (overall yield).

The novel $N$-acylhydrazone derivatives $\mathbf{1 4 a}-\mathbf{h}$ were fully characterized by spectroscopic methods, such as IR, ${ }^{1} \mathrm{H}$ and ${ }^{13} \mathrm{C}$-NMR, their purities were established by HPLC and determined by elemental analysis (CHN). Their molecular formulae were confirmed by mass spectroscopy (ESI-MS). All compounds were obtained as a single tautomer, which was found to be the enolic form, as indicated by signals at $\delta 8.52-8.85(\mathrm{~N}=\mathrm{C}-H), 11.65-12.23(\mathrm{CON} H)$ and $\delta 13.93-14.42 \mathrm{ppm}(\mathrm{O}-H)$ in the ${ }^{1} \mathrm{H}-\mathrm{NMR}$ spectra in DMSO- $d_{6}$ and by signals at $\delta 110.56-111.23(C=\mathrm{C}-\mathrm{OH}), 144.70-152.42(C=\mathrm{N}), 157.56-163.76$ $(C-\mathrm{OH})$ and $164.51-165.98 \mathrm{ppm}(C=\mathrm{O})$ in the ${ }^{13} \mathrm{C}-\mathrm{NMR}$ spectra recorded in the same solvent. The predominance of enolic tautomer is in agreement with recently published data [24-26]. Besides, the presence of only one peak in HPLC chromatogram and a single imine-hydrogen signal in the ${ }^{1} \mathrm{H}-\mathrm{NMR}$ spectra suggest that condensation reaction was diastereoselective. Carefully comparison of amide and imine hydrogens chemical shift of compounds $\mathbf{1 4 a}-\mathbf{h}$ with previous published NMR data for $N$-acylhydrazones whose stereochemistry had been established by crystallography [17,32,33] suggested the presence of the $E$-diastereoisomer, which was confirmed by performing a NOE experiment on compound $\mathbf{1 4 b}$. Thus, on irradiating at the frequency of the amide hydrogen $(\mathrm{CON} H)$ in $\mathbf{1 4 b}$, a positive NOE was observed for the signal at $\delta 8.71 \mathrm{ppm}$, assigned to imine hydrogen $(\mathrm{C}=\mathrm{N}-H)$, and a positive NOE was also observed for the signal at $\delta 2.89 \mathrm{ppm}\left(\mathrm{CH}_{3}\right)$ on irradiating imine hydrogen $(\mathrm{N}=\mathrm{C}-H)$, thus indicating the $E$-configuration for $\mathrm{C}=\mathrm{N}$ double bond. The predominance of the $E$ diastereoisomer of $N$-acylhydrazone derivatives is consistent with previous works [17,31-37] and has been ascribed to the greater thermodynamic stability of the $E$ in respect to the $Z$ diastereoisomer [36,38].

In addition, an intense NOE observed for amide hydrogen on irradiating the methyl hydrogens suggests that a close flat conformation, featuring an S-cis conformation for C8-C9 bond and amide hydrogen antiperiplanar to carbonyl oxygen (14b-I), predominates over an open or folded conformation, featuring an $S$-trans C8-C9 bond (14b-II) or an amide hydrogen antiperiplanar to carbonyl oxygen (14b-III) or both (14b-IV) (Figure 5). The predominance of conformer 14b-I is likely to be due to additional stability provided by hydrogen bonds between the enolic and carboxyl groups and amide hydrogen and benzothiazine nitrogen lone electron pair (Figure 5). These results are in agreement with 
previous works $[24,32]$ and are likely to reflect also the stereochemical and conformational features of the other compounds of the series.

Figure 5. Possibles conformations of compound 14b (LASSBio-1617).

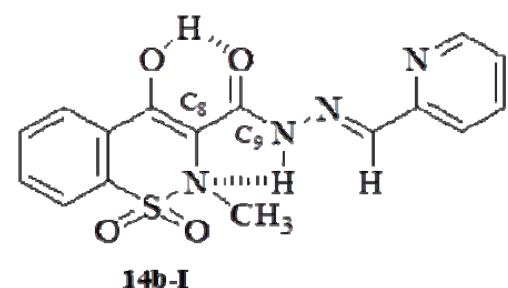<smiles>CN1C(=O)C=CC(=NN=Cc2ccccn2)C1=O</smiles><smiles>CN1C(=O)C(=NN=Cc2ccccn2)[CH][CH]C2=C1c1ccccc1S2(=O)=O</smiles><smiles></smiles>

In order to confirm the results mentioned above and to determine unambiguously the relative configuration of compounds 14a-h, the single crystal of compound 14a (LASSBio-1606) was obtained for X-ray diffraction. The ORTEP [39] view of compound 14a is shown in Figure 6. Crystallographic analysis confirmed the $E$ configuration and revealed a flat conformation, described by the least squares plane through the atoms $\mathrm{N} 2 / \mathrm{C} 3 / \mathrm{C} 4 / \mathrm{O} 16 / \mathrm{O} 15 / \mathrm{C} 14 / \mathrm{N} 17$ with mean deviation from the plane of $0.07 \AA$, featuring the intra-molecular hydrogen bonds involving $\mathrm{N} 17-\mathrm{H} \ldots \mathrm{N} 2$ and $\mathrm{O} 16-\mathrm{H} . . \mathrm{O} 15$, with donor-acceptor distances 2.723(3) $\AA$ and 2.541(3) $\AA$, respectively, corroborating the conclusions suggested by NOE experiment performed with $\mathbf{1 4 b}$.

Figure 6. ORTEP view of compound 14a (LASSBio-1606) with atom displacement ellipsoids drawn at $30 \%$ probability.

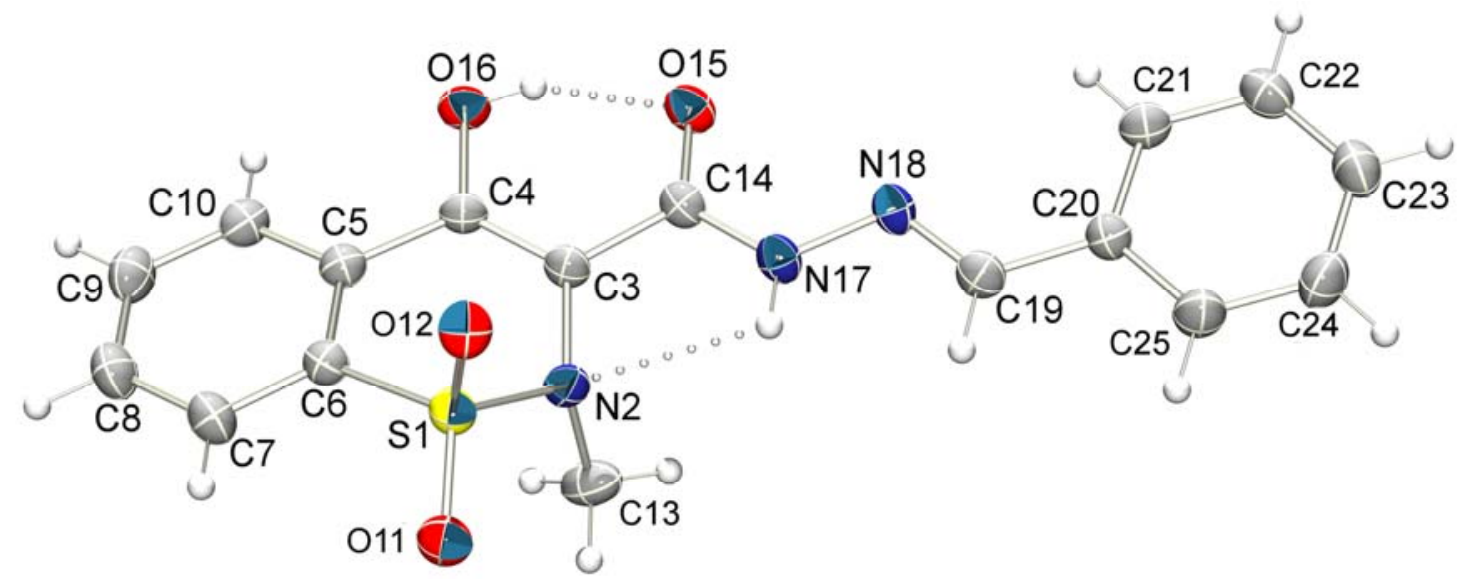




\subsection{Pharmacology}

Compounds 14a-h were evaluated in vivo for their antinociceptive and anti-inflammatory activities at the screening dose of $100 \mu \mathrm{mol} / \mathrm{kg}$. All compounds were administrated orally and piroxicam was used as standard drug, except in the hot plate test, for which morphine was used instead. The antinociceptive activity of compounds $\mathbf{1 4 a}-\mathbf{h}$ was initially evaluated employing the acetic acid-induced abdominal writhing model in mice [40]. As shown in Table 1, all derivatives produced marked inhibition of the acetic acid-induced writhing response. Compound 14e (LASSBio-1604) (90.4\%), which bears a 2-thiophenyl group, the biphenyl analogue 14g (LASSBio-1638) (84.0\%) and 14h, featuring a 3,5-di-tert-butyl-4-hydroxyphenyl group (LASSBio-1639) (82.4\%), were found to be the most active compounds and showed an antinociceptive effect similar to that of piroxicam (95.4\%) at $100 \mu \mathrm{mol} / \mathrm{kg}$.

Table 1. Effect of compounds $14 \mathbf{a}-\mathbf{h}$ and piroxicam $(100 \mu \mathrm{mol} / \mathrm{kg}$, p. o. $)$ on acetic acid-induced writhing test in mice.

\begin{tabular}{ccc}
\hline Compound & Writhing Number ${ }^{\text {a }}$ & \%o of Inhibition \\
\hline Control & $39.4 \pm 4.9$ & - \\
Piroxicam & $1.8 \pm 0.6^{* *}$ & $95.4 \%$ \\
14a (LASSBio-1606) & $9.4 \pm 1.6^{*}$ & $76.1 \%$ \\
14b (LASSBio-1617) & $16.3 \pm 2.5^{*}$ & $58.6 \%$ \\
14c (LASSBio-1605) & $9.8 \pm 5.1 *$ & $75.1 \%$ \\
14d (LASSBio-1607) & $16.6 \pm 2.9^{* *}$ & $57.9 \%$ \\
14e (LASSBio-1604) & $3.8 \pm 1.7^{* *}$ & $90.4 \%$ \\
$\mathbf{1 4 f}($ LASSBio-1637) & $14.7 \pm 2.6^{* *}$ & $62.7 \%$ \\
$\mathbf{1 4 g}$ (LASSBio-1638) & $6.3 \pm 1.5^{* *}$ & $84.0 \%$ \\
$\mathbf{1 4 h}$ (LASSBio-1639) & $6.8 \pm 2.3^{* *}$ & $82.7 \%$ \\
\hline
\end{tabular}

a The readings represent the mean \pm S.E.M. The asterisks denote the significance levels in comparison with control groups $(* p<0.05, * * p<0.01)$.

A dose-response curve was obtained for derivatives 14e, 14g and $14 \mathrm{~h}$ (Table 2). Considering that compounds 14b (LASSBio-1617) and 14f (LASSBio-1637) present the major structural similarity to the standard drug piroxicam, they were also selected for the dose-response study. Compounds $\mathbf{1 4 b}$ and 14e-h produced dose-related inhibition of acetic acid-induced abdominal constrictions in mice and their $\mathrm{ID}_{50}$ and maximum efficacy are summarized in Table 2.

Table 2. Maximum efficacy and $\mathrm{ID}_{50}$ values of compound $\mathbf{1 4 b}, \mathbf{1 4} \mathbf{e}-\mathbf{h}$ and piroxicam on acetic acid-induced writhing test in mice.

\begin{tabular}{ccc}
\hline Compound & ID $_{\mathbf{5 0}}(\boldsymbol{\mu m o l} / \mathbf{k g})$ & Maximum efficacy \\
\hline piroxicam & $0.40(0.0013-115.6)$ & $95.4 \%$ \\
14b (LASSBio-1617) & $115.6(0.17-808.30)$ & $86.00 \%$ \\
14e (LASSBio-1604) & $28.57(6.29-49.61)$ & $90.30 \%$ \\
14f (LASSBio-1637) & $17.19(0.189-156.1)$ & $84.77 \%$ \\
14g (LASSBio-1638) & $14.07(1.06-187.3)$ & $80.20 \%$ \\
14h (LASSBio-1639) & $2.87(0.06-130.5)$ & $88.83 \%$ \\
\hline
\end{tabular}


None of the NAH derivatives were found to be more potent than piroxicam $\left(\operatorname{ID}_{50}=0.40 \mu \mathrm{mol} / \mathrm{kg}\right.$ ) in the acetic acid-induced writhing test, since the most potent antinociceptive in this series was $\mathbf{1 4 h}$ (LASSBio-1639, ID 50 of $2.87 \mu \mathrm{mol} / \mathrm{kg}$ ). Nevertheless, all compounds showed maximum efficacy in the $80-90 \%$ range, like the standard drug piroxicam $(95.4 \%)$. In order to better understand the antinociceptive effect showed by NAH derivatives, the formalin-induced pain test in mice [41] was carried out (Table 3). Formalin is known to produce a biphasic pain behavior. The first transient phase, or neurogenic phase, is ascribed to the direct effect of formalin on sensory $\mathrm{C}$ fibers, and the second prolonged phase, also called inflammatory phase, is associated to the development of an inflammatory response and the release of analgesic mediators [41-43]. With the exception of compound 14b (58\%), none of NAH derivatives were shown to be active in the neurogenic phase of the formalin test (data not shown). On the other hand, at $100 \mu \mathrm{mol} / \mathrm{kg}$, compounds $14 \mathbf{b}, \mathbf{1 4 e}-\mathbf{h}$ were able to inhibit the pain response in the inflammatory phase, with compounds 14f (LASSBio-1637; 60.1\%) and 14g (LASSBio-1638; 54.2\%), which presented similar antinociceptive effect than piroxicam (53.9\%) standing out. Their lack of effect in the neurogenic phase and expressive inhibition of the inflammatory phase of the formalin test, comparable with the response of piroxicam and NSAIDs in general, suggest that these new NAH derivatives are likely to produce their antinociceptive effect by acting on the inflammatory process.

Table 3. Effect of piroxicam NAH analogues $(\mathbf{1 4 a}-\mathbf{h})$ and piroxicam $(100 \mu \mathrm{mol} / \mathrm{kg}$, p.o.) on formalin-induced pain test in mice.

\begin{tabular}{cccc}
\hline Compound & Phase 1 & Phase 2 & $\begin{array}{c}\text { \% of inhibition } \\
\text { Phase 2 }\end{array}$ \\
\hline Control & $50.9 \pm 5.8$ & $194.0 \pm 10.5$ & - \\
Piroxicam & $50.0 \pm 5.8$ & $89.3 \pm 22.8 * *$ & $53.9 \%$ \\
14a (LASSBio-1606) & $49.6 \pm 11.2$ & $172.5 \pm 25.9$ & $11.1 \%$ \\
14b (LASSBio-1617) & $21.3 \pm 5.2 *$ & $119.6 \pm 23.9 *$ & $38.4 \%$ \\
14c (LASSBio-1605) & $36.1 \pm 6.2$ & $176.3 \pm 21.9$ & $9.1 \%$ \\
14d (LASSBio-1607) & $38.8 \pm 8.8$ & $161.4 \pm 27.9$ & $16.8 \%$ \\
14e (LASSBio-1604) & $49.6 \pm 10.7$ & $131.0 \pm 13.1 * *$ & $32.5 \%$ \\
14f (LASSBio-1637) & $50.3 \pm 10.6$ & $77.5 \pm 16.7 *$ & $60.1 \%$ \\
$\mathbf{1 4 g}$ (LASSBio-1638) & $56.6 \pm 10.5$ & $88.8 \pm 18.5 * *$ & $54.2 \%$ \\
$\mathbf{1 4 h}$ (LASSBio-1639) & $54.8 \pm 5.7$ & $140.7 \pm 13.9 *$ & $27.5 \%$ \\
\hline
\end{tabular}

The readings represent the mean \pm S.E.M. The asterisks denote the significance levels in comparison with control groups $(* p<0.05, * * p<0.01)$.

In order to determine any eventual central antinociceptive activity for compounds $\mathbf{1 4} \mathbf{a}-\mathbf{h}$, the hot plate test [31] was carried out in mice. This test is used to evaluate antinociceptive activity mediated by a central mechanism and it is selective for opioid drugs, although sensitive to some sedatives, hypnotics and muscle relaxants [44-47]. None of NAH derivatives were found to be active in this test (data not shown), even 14b (LASSBio-1617), which produced a weak inhibition of pain response in the neurogenic phase of formaline test. Piroxicam was also inactive, as expected. These results reinforce that compounds $\mathbf{1 4 a}-\mathbf{h}$ do not have any central effect and that their antinociceptive effect is mediated peripherically, thus confirming the results found in the formalin-induced pain test. To 
confirm the anti-inflammatory profile of NAH derivatives, as suggested by the results obtained in the formalin test, zymosan A [48,49] and carrageenan-induced peritonitis test in mice [50] were performed. As shown in Table 4, all NAH derivatives significantly inhibited cell recruitment in the zymosan-induced peritonitis test and, with exception of 14e (37.1\%) and 14a (43.7\%), all compounds were found to be similar or more active than piroxicam $(57.4 \%)$ at the dose of $100 \mu \mathrm{mol} / \mathrm{kg}$, highlighting compounds 14g (LASSBio-1638) and 14h (LASSBio-1639), which inhibited 81.3\% and $82.6 \%$ of cell migration, respectively.

Table 4. Effect of piroxicam NAH analogues and piroxicam $(100 \mu \mathrm{mol} / \mathrm{kg}$, p.o.) on zymosan-induced peritonitis in mice.

\begin{tabular}{ccc}
\hline Compound & Cell Number X 10 $\mathbf{6} \mathbf{m L}$ & \% of inhibition \\
\hline Control & $38.0 \pm 1.0$ & - \\
Piroxicam & $16.2 \pm 1.1^{* *}$ & $57.4 \%$ \\
14a (LASSBio-1606) & $21.4 \pm 2.4^{*}$ & $43.7 \%$ \\
$\mathbf{1 4 b}$ (LASSBio-1617) & $9.9 \pm 0.7 * *$ & $73.9 \%$ \\
$\mathbf{1 4 c}$ (LASSBio-1605) & $16.5 \pm 3.7 * *$ & $56.6 \%$ \\
$\mathbf{1 4 d}$ (LASSBio-1607) & $10.6 \pm 0.4 * *$ & $72.1 \%$ \\
$\mathbf{1 4 e}($ LASSBio-1604) & $23.9 \pm 1.7 * *$ & $37.1 \%$ \\
$\mathbf{1 4 f}($ LASSBio-1637) & $8.1 \pm 1.8^{* *}$ & $78.7 \%$ \\
$\mathbf{1 4 g}($ LASSBio-1638) & $7.1 \pm 0.6 * *$ & $81.3 \%$ \\
$\mathbf{1 4 h}($ LASSBio-1639) & $6.6 \pm 1.3 * *$ & $82.6 \%$ \\
\hline
\end{tabular}

The readings represent the mean \pm S.E.M. The asterisks denote the significance levels in comparison with control groups $(* p<0.05, * * p<0.01)$.

In the carrageenan-induced peritonitis test (Table 5) all NAH derivatives were able to inhibit cell migration similarly or more effectively than piroxicam (25.8\%), including 14c (LASSBio-1605; 62.2\%), 14a (LASSBio-1606; 57.4\%) and 14d (LASSBio-1607; 42.3\%), which were not active in the second phase of formalin-induced pain test.

Table 5. Effect of piroxicam NAH analogues and piroxicam $(100 \mu \mathrm{mol} / \mathrm{kg}$, p.o.; mean \pm S.E.M.) on carrageenan-induced peritonitis in mice.

\begin{tabular}{ccc}
\hline Compound & Cell Number X 10 $\mathbf{6} \mathbf{m L}$ & \% of inhibition \\
\hline Control & $20.9 \pm 1.6^{* *}$ & - \\
Piroxicam & $15.5 \pm 0.3^{* *}$ & $25.8 \%$ \\
14a (LASSBio-1606) & $8.9 \pm 0.5^{* *}$ & $57.4 \%$ \\
$\mathbf{1 4 b}$ (LASSBio-1617) & $16.2 \pm 0.7 * *$ & $22.5 \%$ \\
$\mathbf{1 4 c}$ (LASSBio-1605) & $7.9 \pm 0.8^{* *}$ & $62.2 \%$ \\
$\mathbf{1 4 d}$ (LASSBio-1607) & $12.0 \pm 1.5 * *$ & $42.6 \%$ \\
$\mathbf{1 4 e}$ (LASSBio-1604) & $5.4 \pm 0.6^{* *}$ & $74.2 \%$ \\
$\mathbf{1 4 f}($ LASSBio-1637) & $5.6 \pm 0.5 * *$ & $73.2 \%$ \\
$\mathbf{1 4 g}$ (LASSBio-1638) & $4.7 \pm 0.7 * *$ & $77.5 \%$ \\
$\mathbf{1 4 h}$ (LASSBio-1639) & $3.8 \pm 0.6 * *$ & $81.8 \%$ \\
\hline
\end{tabular}

The asterisks denote the significance levels in comparison with control groups ${ }^{*} p<0.05$, ** $p<0.01)$. 
LASSBio-1639 (14h) and LASSBio-1638 (14g) were the most active compounds, inhibiting 81.8\% and $77.5 \%$ of cell migration, respectively, followed by LASSBio-1604 (14e), which, despite being the least active compound in zymosan-induced peritonitis test, showed inhibition of $74.2 \%$ in carrageenaninduced peritonitis test.

In order to investigate if the anti-inflammatory effect of NAH derivatives were COX inhibitiondependent, like piroxicam, compounds $\mathbf{1 4 b}$ and $\mathbf{1 4 f}$ were selected for in vitro assay for their ability of inhibiting COX-1 and COX-2 isoforms [51]. Despite their antinociceptive and anti-inflammatory activities, in vivo, none of the compounds were able to inhibit COX at concentration of $10 \mu \mathrm{M}$, suggesting that they may act in a different way than NSAIDs (data not shown) or would be significantly less potent than the prototype piroxicam.

\section{Experimental}

\subsection{General}

Reagents and solvents were obtained from commercial sources (Sigma-Aldrich, Alfa Aesar) and used as received. Reaction progress was monitored by thin-layer chromatography (TLC) on commercial silica gel plates (KieselGel 60 F245 on aluminum sheets, Merck) and visualized by UV-light (254 and $365 \mathrm{~nm}$ ). Column chromatography purifications were carried out using silica gel Merck 230-400 Mesh. Melting points were determined on a Quimis Q240.23 apparatus and are uncorrected. ${ }^{1} \mathrm{H}-$ and

${ }^{13} \mathrm{C}$ - nuclear magnetic resonance spectra were recorded in DMSO- $d_{6}$ solutions on a Bruker Avance 200 $\mathrm{MHz}$ or on a Varian $400 \mathrm{MHz}$ instrument. Chemical shift $(\delta)$ are given in parts per million (ppm) down field from tetramethylsilane (TMS) and couple constants $(J)$ are given in Hertz $(\mathrm{Hz})$; splitting patterns are reported as follows: s, singlet; $d$, doublet; dd, doublet of doublets; ddd, doublet of doublets of doublets; t, triplet; q, quartet; m, multiplet; br, broad. Electrospray ionization mass spectra (ESI-MS) were acquired using a Micromass quadrupole-time-of-flight (QTOF) spectrometer operating in a positive mode. Infrared (IR) spectra were performed in bromide potassium (KBr) disks on Nicoleta Magna IR 760 spectrometer. HPLC analysis were performed on a Shimadzu 20A using a C18 column $(4,6 \mathrm{~mm} \times 250 \mathrm{~mm}, 5 \mu \mathrm{M})$ eluted with $\mathrm{MeCN} / \mathrm{H}_{2} \mathrm{O}(90: 10 ; 70: 30$ or 45:55) over 15 or 20 min at flow rate of $1 \mathrm{~mL} \cdot \mathrm{min}^{-1}$, with $\mathrm{UV}$ detection at $254 \mathrm{~nm}$.

4-Hydroxy-2-methyl-2H-1,2-benzothiazine-3-carbohydrazide 1,1-dioxide (16). A mixture of compound 15 (2.000 g, $7.06 \mathrm{mmol})$, and hydrazine hydrate $80 \%(6.8 \mathrm{~mL}, 137.4 \mathrm{mmol})$ in ethanol $(40,0 \mathrm{~mL})$ was stirred under reflux for $2 \mathrm{~h}$, when completion of reaction was indicated by TLC. The mixture was partially concentrated under vacuum, followed by addition of water and $\mathrm{HCl} 37 \%$ until precipitation. The solid was filtered and washed with water and cold ethanol to furnish compound 22 (1.256 g, 68\%), which had the following properites: Mp 198-199 ${ }^{\circ} \mathrm{C} ; \mathrm{R}_{f}=0.40\left(\mathrm{CH}_{2} \mathrm{Cl}_{2} / \mathrm{MeOH}, 9: 1\right)$. IR (KBr): 3335, 3282, 1621, 1344, $1041 \mathrm{~cm}^{-1} .{ }^{1} \mathrm{H}-\mathrm{NMR}$ (DMSO- $\left.d_{6}\right): \delta=2.74$ (s, 3H, CH3), 7.85-7.91 (m, 3H, ArH), 8.00-7.95 (m, 1H, ArH), 10.15 ppm (br, 1H, CONH). ${ }^{13} \mathrm{C}-\mathrm{NMR}$ (DMSO-d6): $\delta=110.97$, $124.49,126.44,128.94,132.92,133.85,134.59$, 155.87, 166.44. ESI-HRMS $\mathrm{m} / z=270.04543$ $[\mathrm{M}+\mathrm{H}]^{+}$. Anal. calcd for $\mathrm{C}_{10} \mathrm{H}_{11} \mathrm{~N}_{3} \mathrm{O}_{4} \mathrm{~S}$ : C 44.60, H 4.12, N 15.60; found: C 44.62, H 4.11, N 15.44 . 
General Procedure for Preparation of Compounds 14a-h

A mixture of compound $16(0.37 \mathrm{mmol})$ and the corresponding aromatic or heteroaromatic aldehydes $(0.37 \mathrm{mmol})$ in absolute ethanol $(10 \mathrm{~mL})$ containing one drop of $37 \%$ hydrochloric acid was stirred at room temperature for ca $30 \mathrm{~min}$, until reaction completion (as indicated by TLC). Then the mixture was poured in cold water and filtered. The residue was washed with water and hot hexane and dried under vacuum to produce the desired $N$-acylhydrazone derivatives $14 \mathbf{a}-\mathbf{h}$. When necessary, further purification was performed by silica gel column chromatography to give compounds $\mathbf{1 4 a - h}$ with purity of over $98 \%$ by HPLC.

4-Hydroxy-2-methyl-N'-[(E)-phenylmethylidene]-2H-1,2-benzothiazine-3-carbohydrazide 1,1-dioxide (14a). The title compound was obtained by condensation of $\mathbf{1 6}$ with benzaldehyde as a white powder

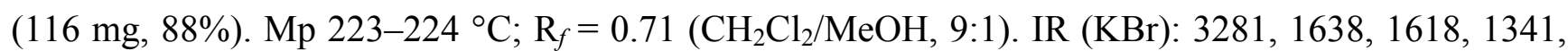
1181, $956 \mathrm{~cm}^{-1} .{ }^{1} \mathrm{H}-\mathrm{NMR}\left(\mathrm{DMSO}-d_{6}\right): \delta=2.85\left(\mathrm{~s}, 3 \mathrm{H}, \mathrm{CH}_{3}\right), 7.48-7.49(\mathrm{~m}, 3 \mathrm{H}, \mathrm{Ar} H), 7.74(\mathrm{~d}, J=2 \mathrm{~Hz}$, 2H, $\operatorname{Ar} H), 7.90-7.92(\mathrm{~m}, 3 \mathrm{H}, \operatorname{Ar} H), 8.02-8.05(\mathrm{~m}, 1 \mathrm{H}, \operatorname{Ar} H), 8.68(\mathrm{~s}, 1 \mathrm{H}, \mathrm{N}=\mathrm{CH}), 11.95(\mathrm{~s}, 1 \mathrm{H}$, $\mathrm{CON} H$ ), $14.23(\mathrm{br}, 1 \mathrm{H}, \mathrm{OH}) .{ }^{13} \mathrm{C}-\mathrm{NMR}$ (DMSO- $d_{6}$ ): $\delta=111.14,124.75,126.79,127.96,128.32$, 129.48, 131.18, 133.62, 134.10, 134.45, 134.76, 151.47, 158.10, 165.63. ESI-HRMS $m / z=358.0856$ $[\mathrm{M}+\mathrm{H}]^{+}$. Anal. calcd. For $\mathrm{C}_{17} \mathrm{H}_{15} \mathrm{~N}_{3} \mathrm{O}_{4} \mathrm{~S}$ : C 57.13, H 4.23, N 11.76; found: C 57.25, H 4.24, N 11.44. HPLC (C18, acetonitrile-water, 7:3, $254 \mathrm{~nm})$ : ret. time: $5.868 \mathrm{~min}$; peak area $=98,299 \%$.

4-Hydroxy-2-methyl-N'-[(E)-pyridinyl-2-methylidene]-2H-1,2-benzothiazine-3-carbohydrazide 1,1dioxide (14b). The title compound was obtained by condensation of 16 with 2-pyridinecarboxaldehyde as a light yellow powder (90 mg, 71\%). Mp 253-254 ${ }^{\circ} \mathrm{C} ; \mathrm{R}_{f}=0.33\left(\mathrm{CH}_{2} \mathrm{Cl}_{2} / \mathrm{MeOH}, 9: 1\right)$. IR (KBr): 3344, 1666, 1597, 1342, 1177, $962 \mathrm{~cm}^{-1}$. ${ }^{1} \mathrm{H}-\mathrm{NMR}\left(\mathrm{DMSO}-d_{6}\right): \delta=2.85\left(\mathrm{~s}, 3 \mathrm{H}, \mathrm{CH}_{3}\right), 7.44(\mathrm{~m}, 1 \mathrm{H}$, $\operatorname{Ar} H), 7.85-7.88(\mathrm{~m}, 1 \mathrm{H}, \operatorname{Ar} H), 7.89-7.90(\mathrm{t}, J=4,1 \mathrm{H}, \operatorname{Ar} H), 7.90-7.94$ (m, 1H, $\operatorname{Ar} H), 7.97(\mathrm{~d}, J=8$, $1 \mathrm{H}, \operatorname{Ar} H), 8.02-8.05(\mathrm{~m}, 1 \mathrm{H}, \operatorname{Ar} H), 8.64(\mathrm{ddd}, J=8 \mathrm{~Hz}, J=4 \mathrm{~Hz}, J=2 \mathrm{~Hz}, 1 \mathrm{H}, \operatorname{Ar} H), 8.69(\mathrm{~s}, 1 \mathrm{H}$, $\mathrm{N}=\mathrm{C} H), 12.14(\mathrm{~s}, 1 \mathrm{H}, \mathrm{CON} H), 14.09(\mathrm{br}, 1 \mathrm{H}, \mathrm{OH}) .{ }^{13} \mathrm{C}-\mathrm{NMR}\left(\mathrm{DMSO}-d_{6}\right): \delta=111.13,120.81,124.78$, $125.35,126.86,128.23,133.75,134.14,134.78,137.53,150.22,151.40,153.44,158.47,165.98$; ESI-HRMS $m / z=359.0809[\mathrm{M}+\mathrm{H}]^{+}$. Anal. calcd for $\mathrm{C}_{16} \mathrm{H}_{14} \mathrm{~N}_{4} \mathrm{O}_{4} \mathrm{~S}$ : C 53.62, $\mathrm{H}$ 3.94, N 15.63; found: C 53.48, H 3.92, N 15.59. HPLC (C18, acetonitrile-water, 45:55, $254 \mathrm{~nm}$ ): ret. time: 3.916 min; peak area $=98,484 \%$.

4-Hydroxy-2-methyl-N'-\{(E)-[4-(2-propanyl)phenyl]phenylmethylidene\}-2H-1,2-benzothiazine-3carbohydrazide 1,1-dioxide (14c). The title compound was obtained by condensation of 16 with 4-isopropylbenzaldehyde as a white powder $(131 \mathrm{mg}, 89 \%)$. Mp 228-229 ${ }^{\circ} \mathrm{C} ; \mathrm{R}_{f}=0.82$ $\left(\mathrm{CH}_{2} \mathrm{Cl}_{2} / \mathrm{MeOH}, 9: 1\right)$. IR (KBr): 3283, 1638, 1615, 1348, 1182, $958 \mathrm{~cm}^{-1}$. ${ }^{1} \mathrm{H}-\mathrm{NMR}$ (DMSO- $\left.d_{6}\right): \delta=1.23$ $\left(\mathrm{d}, J=6 \mathrm{~Hz}, 6 \mathrm{H}, \mathrm{CH}\left(\mathrm{CH}_{3}\right)_{2}\right), 2.84\left(\mathrm{~s}, 3 \mathrm{H}, \mathrm{CH}_{3}\right), 2.96\left(\mathrm{~h}, 1 \mathrm{H}, \mathrm{CH}\left(\mathrm{CH}_{3}\right)_{2}\right), 7.36(\mathrm{~d}, J=8 \mathrm{~Hz}, 2 \mathrm{H}, \mathrm{Ar} H)$, $7.67(\mathrm{~d}, J=8 \mathrm{~Hz}, 2 \mathrm{H}, \operatorname{Ar} H), 7.91(\mathrm{~m}, 3 \mathrm{H}, \mathrm{Ar} H), 8.02-8.06(\mathrm{~m}, 1 \mathrm{H}, \mathrm{Ar} H), 8.64(\mathrm{~s}, 1 \mathrm{H}, \mathrm{N}=\mathrm{CH}), 11.89$ $(\mathrm{s}, 1 \mathrm{H}, \mathrm{CON} H), 14.24(\mathrm{br}, 1 \mathrm{H}, \mathrm{OH}) .{ }^{13} \mathrm{C}-\mathrm{NMR}\left(\mathrm{DMSO}-d_{6}\right): \delta=24.17,33.97,111.14,124.75,126.77$, $127.47,128.09,128.34,132.14,133.61,134.12$, 134.74, 151.51, 151.89, 158.01, 165.51. ESI-HRMS $m / z=400.1309[\mathrm{M}+\mathrm{H}]^{+}$. Anal. calcd for $\mathrm{C}_{20} \mathrm{H}_{21} \mathrm{~N}_{3} \mathrm{O}_{4} \mathrm{~S}: \mathrm{C} 60.13, \mathrm{H} 5.30, \mathrm{~N} 10.52$; found: $\mathrm{C} 60.30, \mathrm{H}$ 5.27, N 10.39. HPLC (C18, acetonitrile-water, 7:3, $254 \mathrm{~nm}$ ): ret. time: $10.977 \mathrm{~min}$; peak area =98,127\%. 
4-Hydroxy-2-methyl-N'-\{(E)-[4-(dimethylamino) phenyl] phenylmethylidene\}-2H-1,2-benzothiazine-3carbohydrazide 1,1-dioxide (14d). The title compound was obtained by condensation of $\mathbf{1 6}$ with 4-dimethylaminobenzaldehyde as an orange powder (137 mg, 89\%). Mp 217-218 ${ }^{\circ} \mathrm{C} ; \mathrm{R}_{f}=0.70$ $\left(\mathrm{CH}_{2} \mathrm{Cl}_{2} / \mathrm{MeOH}, 9: 1\right)$. IR (KBr): 3287, 1598, 1344, 1181, $956 \mathrm{~cm}^{-1} .{ }^{1} \mathrm{H}-\mathrm{NMR}\left(\mathrm{DMSO}-d_{6}\right): \delta=2.83$ (s, $\left.3 \mathrm{H}, \mathrm{CH}_{3}\right), 2.99\left(\mathrm{~s}, 6 \mathrm{H}, \mathrm{N}\left(\mathrm{CH}_{3}\right)_{2}\right), 6.78(\mathrm{~d}, J=8 \mathrm{~Hz}, 2 \mathrm{H}, \operatorname{Ar} H), 7.56(\mathrm{~d}, J=8 \mathrm{~Hz}, 2 \mathrm{H}, \operatorname{Ar} H)$, 7.89-7.93 (m, 3H, ArH), 8.00-8.05 (m, 1H, ArH), 8.52 (s, 1H, N=CH), 11.65 (s, 1H, CONH), 14.42 (br, $1 \mathrm{H}, \mathrm{OH}) ;{ }^{13} \mathrm{C}-\mathrm{NMR}\left(\mathrm{DMSO}-d_{6}\right): \delta=111.22,112.43,121.67,124.72,126.65,128.47,129.42$, 132.14, 133.42, 134.06, 134.68, 152.27, 152.37, 157.56, 164.90. ESI-HRMS $m / z=401.1276[\mathrm{M}+\mathrm{H}]^{+}$. Anal. calcd. for $\mathrm{C}_{19} \mathrm{H}_{20} \mathrm{~N}_{4} \mathrm{O}_{4} \mathrm{~S}$ : C 56.99, $\mathrm{H}$ 5.03, N 13.99; found: C 56.69, H 5.03, N 13.99. HPLC (C18, acetonitrile-water, 7:3, $254 \mathrm{~nm}$ ): ret. time: $4.420 \mathrm{~min}$; peak area $=98,349 \%$.

4-Hydroxy-2-methyl-N'-[(E)-thiophenyl-2-methylidene]-2H-1,2-benzothiazine-3-carbohydrazide 1,1dioxide (14e). The title compound was obtained by condensation of 16 with thiophenecarboxaldehyde as a white powder (124 mg, 92\%). $\mathrm{Mp} 236-237^{\circ} \mathrm{C} ; \mathrm{R}_{f}=0.63\left(\mathrm{CH}_{2} \mathrm{Cl}_{2} / \mathrm{MeOH}, 9: 1\right)$. IR (KBr): 3267 , 1636, 1614, 1338, 1181, $957 \mathrm{~cm}^{-1} .{ }^{1} \mathrm{H}-\mathrm{NMR}$ (DMSO-d $): \delta=2.83\left(\mathrm{~s}, 3 \mathrm{H}, \mathrm{CH}_{3}\right), 7.17$ (t, $J=4 \mathrm{~Hz}, 1 \mathrm{H}$, $\operatorname{Ar} H), 7.52(\mathrm{~d}, J=2 \mathrm{~Hz}, 1 \mathrm{H}, \operatorname{Ar} H), 7.73(\mathrm{~d}, J=4,1 \mathrm{H}, \operatorname{Ar} H), 7.90-7.97$ (m, 3H, $\operatorname{Ar} H), 8.01-8.06(\mathrm{~m}$, $1 \mathrm{H}, \operatorname{Ar} H), 8.84(\mathrm{~s}, 1 \mathrm{H}, \mathrm{N}=\mathrm{CH}), 11.91(\mathrm{~s}, 1 \mathrm{H}, \mathrm{CON} H), 14.16 \mathrm{ppm}(\mathrm{br}, 1 \mathrm{H}, \mathrm{OH}) ;{ }^{13} \mathrm{C}-\mathrm{NMR}\left(\mathrm{DMSO}-d_{6}\right)$ : $\delta=111.12,124.74,126.77,128.31,128.59,130.41,132.53,133.61,134.12,134.70,139.11,146.30$, 157.98, 165.31; ESI-HRMS $m / z=364.0417[\mathrm{M}+\mathrm{H}]^{+}$. Anal. calcd. for $\mathrm{C}_{15} \mathrm{H}_{13} \mathrm{~N}_{3} \mathrm{O}_{4} \mathrm{~S}_{2}$ : C 49.57, H 3.61, N 11.56; found: C 49.58, H 3.61, 11.27. HPLC (C18, acetonitrile-water, 7:3, $254 \mathrm{~nm}$ ): ret. time: 5.378 min; peak area $=98,866 \%$.

4-Hydroxy-2-methyl-N'-[(E)-1,3-thiazolyl-2-methylidene]-2H-1,2-benzothiazine-3-carbohydrazide 1,1-dioxide (14f). The title compound was obtained by condensation of $\mathbf{1 6}$ with 2-thiazolecarboxaldehyde $(0.04 \mathrm{~mL}, 0.37 \mathrm{mmol})$ as a white powder $(93 \mathrm{mg}, 63 \%)$. Mp 224-225 ${ }^{\circ} \mathrm{C}$; $\mathrm{R}_{f}=0.36\left(\mathrm{CH}_{2} \mathrm{Cl}_{2} /-\mathrm{MeOH}, 9: 1\right)$. IR ( $\left.\mathrm{KBr}\right) 3223,1624,1355,1182,948 \mathrm{~cm}^{-1} .{ }^{1} \mathrm{H}-\mathrm{NMR}$ (DMSO- $\left.d_{6}\right): \delta$ $=2.85\left(\mathrm{~s}, 3 \mathrm{H}, \mathrm{CH}_{3}\right), 7.89(\mathrm{dd}, J=4 \mathrm{~Hz}, J=2 \mathrm{~Hz}, 1 \mathrm{H}, \mathrm{Ar} H), 7.90-1.95(\mathrm{~m}, 3 \mathrm{H}, \mathrm{Ar} H), 7.99(\mathrm{~d}, J=4$, $1 \mathrm{H}, \operatorname{Ar} H), 8.03-8.05(\mathrm{~m}, 1 \mathrm{H}, \mathrm{Ar} H), 8.85$ (s, 1H, N=CH), 12.23 (s, 1H, CONH), 13.93 (br, 1H, OH). ${ }^{13} \mathrm{C}-\mathrm{NMR}$ (DMSO- $d_{6}$ ): $\delta=110.55,122.63,124.25,125.35,127.58,133.28,133.62,134.18,144.28$, 144.70, 158.01, 163.76, 165.23. ESI-HRMS $m / z=365.0378[\mathrm{M}+\mathrm{H}]^{+}$. Anal. calcd. for $\mathrm{C}_{14} \mathrm{H}_{12} \mathrm{~N}_{4} \mathrm{O}_{4} \mathrm{~S}_{2}$ : C 46.14, H 3.32, N 15.38; found C 46.03, H 3.39, N 15.42. HPLC (C18, acetonitrile-water, 45:55, $254 \mathrm{~nm}$ ): ret. time: $11.831 \mathrm{~min}$; peak area $=99,751 \%$.

4-Hydroxy-2-methyl-N'-[(E)-4-biphenylphenylmethylidene]-2H-1,2-benzothiazine-3-carbohydrazide 1,1-dioxide (14g). The title compound was obtained by condensation of $\mathbf{1 6}$ with 4-biphenylcarboxaldehyde as a light green powder (146 mg, 91\%). Mp 215-216 ${ }^{\circ} \mathrm{C} ; \mathrm{R}_{f}=0.72$ $\left(\mathrm{CH}_{2} \mathrm{Cl}_{2} / \mathrm{MeOH}, 9: 1\right)$. IR (KBr): 3271, 1613, 1343, 1182, $959 \mathrm{~cm}^{-1} .{ }^{1} \mathrm{H}-\mathrm{NMR}$ (DMSO- $\left.d_{6}\right): \delta=2.86(\mathrm{~s}$, $\left.3 \mathrm{H}, \mathrm{CH}_{3}\right), 7.36-7.53$ (m, 3H, ArH), 7.74 (d, $\left.J=8 \mathrm{~Hz}, 2 \mathrm{H}, \mathrm{ArH}\right), 7.81-7.82$ (m, 3H, ArH), 7.87-7.93 (m, 4H, $\operatorname{Ar} H), 8.03-8.06(\mathrm{~m}, 1 \mathrm{H}, \mathrm{ArH}), 8.72(\mathrm{~s}, 1 \mathrm{H}, \mathrm{N}=\mathrm{CH}), 12.01(\mathrm{~s}, 1 \mathrm{H}, \mathrm{CONH}), 14.24$ (br, 1H, OH).

${ }^{13} \mathrm{C}-\mathrm{NMR}\left(\mathrm{DMSO}-d_{6}\right): \delta=111.15,124.76,126.80,127.28,128.33,128.59,129.60,133.54,133.65$, 134.13, 134.74, 139.79, 142.66, 150.99, 158.13, 165.62.; ESI-HRMS $m / z=434.1165[\mathrm{M}+\mathrm{H}]^{+}$. Anal. 
calcd. for $\mathrm{C}_{23} \mathrm{H}_{19} \mathrm{~N}_{3} \mathrm{O}_{4} \mathrm{~S}$ : C 63.73, $\mathrm{H}$ 4.42, N 9.69; found: C 63.87, H 4.39, N 9.65. HPLC (C18, acetonitrile-water, 9:1, $254 \mathrm{~nm}$ ): ret. time: $4.653 \mathrm{~min}$; peak area $=99,145 \%$.

4-Hydroxy-2-methyl-N'-\{(E)-[3,5-di-terc-buthyl-4-hydroxy] phenylmethylidene $\}$-2H-1,2-benzothiazine3-carbohydrazide 1,1-dioxide (14h). The title compound was obtained by condensation of 16 with 3,5-di-tert-buthyl-4-hydroxyphenylcarboxaldehyde as a light green powder (161 mg, 90\%). Mp 249-251 ${ }^{\circ} \mathrm{C} ; \mathrm{R}_{f}=0.61\left(\mathrm{CH}_{2} \mathrm{Cl}_{2} / \mathrm{MeOH}, 9: 1\right)$. IR (KBr): 3287, 1645, 1617, 1348, 1183, $954 \mathrm{~cm}^{-1}$. ${ }^{1} \mathrm{H}-\mathrm{NMR}\left(\mathrm{DMSO}-d_{6}\right): \delta=1.42\left(\mathrm{~s}, 18 \mathrm{H}, \mathrm{C}\left(\mathrm{CH}_{3}\right)_{3}\right), 2.83\left(\mathrm{~s}, 3 \mathrm{H}, \mathrm{CH}_{3}\right), 7.49(\mathrm{~s}, 2 \mathrm{H}, \mathrm{ArH}), 7.53(\mathrm{~s}, 1 \mathrm{H}$, $\mathrm{OH}), 7.91-8.02(\mathrm{~m}, 4 \mathrm{H}, \operatorname{Ar} H), 8.59(\mathrm{~s}, 1 \mathrm{H}, \mathrm{N}=\mathrm{CH}), 11.71(\mathrm{~s}, 1 \mathrm{H}, \mathrm{CONH}), 14.25(\mathrm{br}, 1 \mathrm{H}, \mathrm{OH})$; ${ }^{13} \mathrm{C}-\mathrm{NMR}\left(\mathrm{DMSO}-d_{6}\right): \delta=30.11,34.50,110.64,124.30,125.11,126.16,134.16,139.24,152.42$, 156.66, 157.09, 164.51. ESI-HRMS $m / z=486.2056[\mathrm{M}+\mathrm{H}]^{+}$. Anal. calcd for $\mathrm{C}_{25} \mathrm{H}_{31} \mathrm{~N}_{3} \mathrm{O}_{5} \mathrm{~S}: \mathrm{C} 61.83$, H 6.43, N 8.65; found: C 61.93, H 6.39, N 8.61. HPLC (C18, acetonitrile-water, 9:1, $254 \mathrm{~nm})$ : ret. time: $5.333 \mathrm{~min}$; peak area $=99,697 \%$.

\subsection{X-ray Crystallography}

A colorless prismatic single crystal of compound 14a (LASSBio-1606) suitable for x-ray study was obtained by slow evaporation of a solution of dichloromethane-dimethyl sulfoxide (1:15) at room temperature 295(2) K. Data collection was performed using the Enraf-Nonius CAD-4 diffractometer operating with $\mathrm{Cu}-\mathrm{K} \alpha$ radiation at room temperature. 3718 data points were collected of what 3004 are symmetry independent $\left(\mathrm{R}_{\text {int }}=0.0267\right)$. The molecule crystallizes in the $\mathrm{C} 2 / \mathrm{c}$ space group, having $\mathrm{Z}=8$. Structure solution was obtained using Direct Methods implemented in SHELXS [52] and the model refinement was performed with full matrix least squares on $\mathrm{F}^{2}$ using SHELXL [52], with final residuals $\mathrm{R} 1=0.056$, wR2 $=0.148$ for 2633 observed data with $\mathrm{I}>2 \sigma(\mathrm{I})$, and $\mathrm{R} 1=0.071$, wR2 $=0.299$ for all data. The crystal packing is mediated by a pair of intermolecular hydrogen short contact of type $\mathrm{N} 17-\mathrm{H} 17 \ldots \mathrm{O} 12^{\mathrm{i}}$ with donor-acceptor distance $3.156(3) \AA$ and DHA angle $149.3^{\circ}$, forming dimmers about an inversion center, and further stabilization is due to weak interactions of types $\mathrm{C} 10-\mathrm{H} \ldots \mathrm{O} 12^{\mathrm{ii}}, \mathrm{C} 13-\mathrm{H} \ldots \mathrm{O} 15^{\mathrm{iii}}$ and $\mathrm{C} 22-\mathrm{H} \ldots \mathrm{O} 11^{\mathrm{iv}}$. Hydrogen interactions geometry is given in Table 6. The programs ORTEP-3 [39], SHELXS/SHELXL [52] were used within WinGX [53] software package.

Table 6. Intramolecular and intermolecular hydrogen bonds and weak interactions.

\begin{tabular}{cccccc}
\hline D-H...A & D-H $(\AA)$ & H...A $(\AA)$ & D...A $(\AA)$ & D-H...A $\left(^{\circ}\right)$ & Symmetry operation \\
\hline $\mathrm{N} 17-\mathrm{H} 17 \ldots \mathrm{N} 2$ & 0.86 & 2.33 & $2.723(3)$ & 108.1 & \\
$\mathrm{O} 16-\mathrm{H} 16 \ldots \mathrm{O} 15$ & 0.82 & 1.81 & $2.541(3)$ & 147.4 & \\
$\mathrm{~N} 17-\mathrm{H} 17 \ldots \mathrm{O} 12^{\mathrm{i}}$ & 0.86 & 2.39 & $3.156(3)$ & 149.3 & (i) $1 / 2-\mathrm{x}, 1 / 2-\mathrm{y},-\mathrm{z}$ \\
$\mathrm{C} 10-\mathrm{H} 10 \ldots \mathrm{O} 12^{\text {ii }}$ & 0.93 & 2.69 & $3.268(4)$ & 121.3 & (ii) $1-\mathrm{x},-\mathrm{y},-\mathrm{z}$ \\
$\mathrm{C} 13-\mathrm{H} 13 \mathrm{~B} \ldots \mathrm{O} 15^{\text {iii }}$ & 0.96 & 2.55 & $3.466(4)$ & 158.7 & (iii) $1-\mathrm{x}, 1-\mathrm{y},-\mathrm{z}$ \\
$\mathrm{C} 22-\mathrm{H} 22 \ldots \mathrm{O} 11^{\text {iv }}$ & 0.93 & 2.48 & $3.373(4)$ & 162.3 & (iv) $\mathrm{x}, 1-\mathrm{y},-1 / 2+\mathrm{z}$ \\
\hline
\end{tabular}




\subsection{Pharmacological Evaluation}

\subsubsection{Animals}

Swiss mice weighing 20-30 g (from the BIOCEN-UFAL) were housed in group cages and maintained on a $12 \mathrm{~h} \mathrm{light} / 12 \mathrm{~h}$ dark cycle. Animals had free access to food and water at all times. Experiments were carried out according to a protocol approved by the Animal Welfare Committee of Federal University of Alagoas (UFAL) (Number: 026681/2009-23), and in according with the ethical guidelines for investigation of experimental pain in conscious animals

\subsubsection{Reagents}

Acetic acid (Merck), arabic gum (Sigma Aldrich), morphine sulphate (Dimorf-Cristalia-BR) and piroxicam (Merck) were obtained from commercial sources. A solution of formalin $2.5 \%$ was prepared with formaldehyde (Merck) in saline ( $\mathrm{NaCl}$ 0.9\%). Piroxicam and compounds $\mathbf{1 4 a}-\mathbf{h}$ were used as suspension in arabic gum in all the experiments and oral administrations.

\subsubsection{Acetic Acid-induced Writhing Test}

This test was performed as described by Collier et al. [40]. Acetic acid $(0.6 \%$, v/v) was administered i.p. in a volume of $0.1 \mathrm{~mL} / 10 \mathrm{~g}$. The number of writhes, a response consisting of contraction of an abdominal wall, pelvic rotation followed by hind limb extension, was counted during continuous observation for $20 \mathrm{~min}$ beginning from $5 \mathrm{~min}$ after the acetic acid injection. Piroxicam and compounds 14a-h (all $100 \mu \mathrm{mol} / \mathrm{kg}$, oral administration) were administered $60 \mathrm{~min}$ before the acetic acid injection. Antinociceptive activity was expressed as inhibition percent of the usual number of writhing observed in control animals. Dose-response curves were obtained for piroxicam and LASSBio-1604 (14e) (1, 10, 30, 100, $300 \mu \mathrm{mol} / \mathrm{kg})$, LASSBio-1617 (14b) (1, 10, 30, 100, $300 \mu \mathrm{mol} / \mathrm{kg})$, LASSBio-1637 (14f) (1, 10, 30, 100, $300 \mu \mathrm{mol} / \mathrm{kg})$, LASSBio-1638 (14g) (1, 10, 30, $100,300 \mu \mathrm{mol} / \mathrm{kg})$, and LASSBio-1639 (14h) $(1,10,30,100,300 \mu \mathrm{mol} / \mathrm{kg})$ using groups of 8 animals. Control animals received the vehicle. The $\mathrm{ID}_{50}$ values (i.e., dose which reduces response by $50 \%$ relative to the control values) of piroxicam, of compounds $14 \mathrm{e}, 14 \mathrm{a}, 14 \mathrm{f}, 14 \mathrm{~g}$ and $14 \mathrm{~h}$ were determined by linear regression from individual experiments with the linear regression function of the Graph Pad Prisma software.

\subsubsection{Formalin-induced Nociception}

The procedure used was essentially the same as that described previously [41]. Animals received $20 \mathrm{~mL}$ of $2.5 \%$ formalin solution $(0.92 \%$ formaldehyde in saline) in the ventral surface of the right hind paw. Animals were observed from 0 to $5 \mathrm{~min}$ (neurogenic phase) and from 15 to $30 \mathrm{~min}$ (inflammatory phase) and the time that they spent licking the injected paw was recorded and considered as indicative of nociception. Animals received piroxicam or compounds $\mathbf{1 4 a}-\mathbf{h}(100 \mu \mathrm{mol} / \mathrm{kg}$, oral administration) 40 min beforehand. Control animals received vehicle (arabic gum). 


\subsubsection{Hot-plate Test}

Mice were treated according to the method described by Kuraishi et al. [46]. Animals $(\mathrm{n}=6)$ were placed on a hot-plate set at $55 \pm 1{ }^{\circ} \mathrm{C}$. Reaction time was recorded when the animals licked their fore and hind-paws and jumped at 30,60, 90 and $120 \mathrm{~min}$ after oral administration of $100 \mu \mathrm{mol} / \mathrm{kg}$ of piroxicam or compounds $\mathbf{1 4 a}-\mathbf{h}$ or reference drug (morphine, $15 \mu \mathrm{mol} / \mathrm{kg}$. i.p.). Baseline was considered as the mean of reaction time obtained at 30 and $60 \mathrm{~min}$ before administration of derivatives or piroxicam or morphine and was defined as normal reaction of animal to the temperature.

\subsubsection{Zymosan-induced Peritonitis}

Peritoneal inflammation was induced according to the method described by Leite et al. [49]. A solution of Zymosan A (Sigma-Aldrich) (2 mg/mL) was prepared in saline ( $\mathrm{NaCl} \mathrm{0.9 \% )} \mathrm{and} \mathrm{injected}$ into the peritoneal cavity of mice $(0.5 \mathrm{~mL})$. Six hours after injection of Zymosan A, the animals were killed by cervical dislocation and the peritoneal cavity was washed with $3 \mathrm{~mL}$ of cold Hank's. Compounds 14a-h or piroxicam were administered at the dose of $100 \mu \mathrm{mol} / \mathrm{kg}$ (p.o.), $40 \mathrm{~min}$ before Zymosan A injection. Control group received $10 \mathrm{~mL} / \mathrm{kg}$ of vehicle (arabic gum, p.o.). The number of cells was quantified by optical microscope, using the $100 \times$ lens.

\subsubsection{Carrageenan-induced Peritonitis}

Peritoneal inflammation was induced according to the method described by Ferrandiz and Alcaraz [50]. A solution of carrageenan $1 \%$ (Sigma-Aldrich) was prepared in saline $(\mathrm{NaCl} 0.9 \%)$ and injected into the peritoneal cavity of mice $(250 \mu \mathrm{L} /$ animal $)$. Four hours after injection of carrageenan, the animals were killed by cervical dislocation and the peritoneal cavity was washed with $3 \mathrm{~mL}$ of cold Hank's. Compounds 14a-h and piroxicam were administered at the dose of $100 \mu \mathrm{mol} / \mathrm{kg}$ (p.o.), $30 \mathrm{~min}$ before carrageenan injection. Control group received $10 \mathrm{~mL} / \mathrm{kg}$ of vehicle (arabic gum, p.o.). The number of cells was quantified by optical microscope, using $100 \times$ lens.

\subsubsection{Evaluation of Human COX-1/COX-2 Inhibition}

Evaluation of piroxicam and compounds 14b,e for COX-1 and COX-2 inhibition were performed by CEREP Laboratories (Celle L'Evescault, France) using, respectively, assay catalog reference no. 0726 and 0727, and both were carried out as described by Glaser et al. [51]. In these assays, the inhibitory effect of compounds, at concentration of $10 \mu \mathrm{M}$, on activity of human recombinant COX-1 or COX-2, isolated from Sf-9 cells, was quantified by measuring the formation of $\mathrm{PGE}_{2}$, detected by homogeneous time resolved fluorescence (HTRF), from arachidonic acid. The results are expressed as a percent inhibition of the control enzyme activity.

\subsubsection{Test Evaluation of the Inhibition of LOX}

Compounds 14b, 14e-h and piroxicam were evaluated for their ability to inhibit LOX, using the kit for determining the inhibition of LOX (Lipoxygenase Inhibitor Screening Assay Kit, Cayman Chemical Company, Ann Arbor, MI, USA) according to manufacturer's instructions. The test 
compound solutions were prepared using DMSO as solvent and reaction buffer (supplied in kit) to a concentration of $10 \mu \mathrm{M}$.

\subsubsection{Statistical Analysis}

Data obtained from animal experiments are represented by mean \pm standard error of the mean (Mean \pm S.E.M.). Statistical differences between the treated and the control groups were evaluated by test $t$ of Student or ANOVA in the tutorial Prisma ${ }^{\circledR}$. Values were considered significant if $* p<0.05$ and $* * p<0.01$. The $\mathrm{ID}_{50}$ values (i.e., the dose of derivatives $N$-acylhydrazone which reduced the pain response by $50 \%$ in relation to control group values) were determined by linear regression from individual experiments using the GraphPad software (GraphPad Software, San Diego, CA, USA) and are reported as geometric means accompanied by their respective $95 \%$ confidence limits. Maximal inhibition values were calculated at the more effective dose used.

\section{Conclusions}

In general, compounds $\mathbf{1 4} \mathbf{a}-\mathbf{h}$ presented antinociceptive and anti-inflammatory activities in vivo, by oral administration, at the screening dose of $100 \mu \mathrm{mol} / \mathrm{kg}$. Pharmacological evaluation suggest that the NAH derivatives reported herein present a better pharmacological profile than standard drug piroxicam, especially for their markedly activity in acute inflammation models. Moreover, we were able to identify LASSBio-1637 (14f) and LASSBio-1639 (14g) as new antinociceptive and anti-inflammatory prototypes, which are able to inhibit cell recruitment in carrageenan and zymosan-induced peritonitis in more than $70 \%$ and $80 \%$ (dose $=100 \mu \mathrm{mol} / \mathrm{kg}$, p.o), respectively, through a mechanism of action that seems to be distinct of piroxicam and remains to be elucidated.

\section{Supplementary Material}

The structural results for 14a were deposited with the Cambridge Crystallographic Data Centre as Supporting Information, CCDC number: 908020. Copies of the data can be obtained free of charge upon application to CCDC, 12 Union Road, Cambridge CB2 1EZ, United Kingdom (Fax: (44) 1223 336-033; E-mail: deposit@ccdc.cam.ac.uk).

Supplementary materials can be accessed at: http://www.mdpi.com/1420-3049/17/12/14126/s1.

\section{Acknowledgements}

The authors are grateful to FAPERJ, CNPq, CAPES and INCT-INOFAR for financial support.

\section{References}

1. Medzhitov, R. Origin and physiological roles of inflammation. Nature 2008, 454, 428-435.

2. Henson, P.M. Dampening inflammation. Nat. Immunol. 2005, 6, 1179-1181.

3. Gaestel, M.; Kotlyarov, A.; Kracht, M. Targeting innate immunity protein kinase signalling in inflammation. Nat. Rev. Drug Dis. 2009, 8, 480-499. 
4. Lombardino, J.G.; Wiseman, E.H.J. Sudoxicam and Related N-Hetherocyclic Carboxamides of 4-Hidroxy-2H-1,2- benzothiaziene 1,1- Dioxide. Potent Nonsteroidal Antiinflammatory Agents. J. Med. Chem. 1972, 15, 848-849.

5. Whitehouse, M.W. Drugs to treat inflammation: A historical introduction. Curr. Med. Chem. 2005, 12, 2931-2942.

6. Engelhardt, G.; Homma, D.; Schlegel, K.; Ultzmann, R.; Schnitzler, C. Anti-inflammatory, analgesic, antipyretic and related properties of meloxicam, A new non-steroidal anti-inflammatory agent with favourable gastrointestinal tolerance. Inflamm. Res. 1995, 44, 423-433.

7. Bradshaw, D.; Cashin, C.H.; Kennedy, A.D.; Roberts, N.A. Pharmacological and biochemical activities of Tenoxicam (Ro 12-0068), A new non-steroidal anti-inflammatory drug. Agents Actions 1984, 15, 569-577.

8. Balfour, J.A.; Fitton, L.B. Barradell, Lornoxicam: A review of its pharmacology and therapeutic potential in the management of painful and inflammatory conditions. Drugs 1996, 51, 639-657.

9. Hobbs, Y.D.C.; Twomey, T.M.J. Piroxicam pharmacokinetics in man: Aspirin and antacid interaction studies. Clin. Pharmacol. 1979, 19, 270-281.

10. Richy, F.; Scarpignato, C.; Lanas, A.; Reginster, J.-Y. Efficacy and safety of piroxicam revisited. A global meta-analysis of randomized clinical trials. Pharmacol. Res. 2009, 60, 254-263.

11. Dannhardt, G.; Kiefer, W. Cyclooxygenase inhibitors-Current status and future prospects. Eur. J. Med. Chem. 2001, 36, 109-126.

12. Brideau, C.; Kargman, S.; Liu, S.; Dallob, A.L. A human whole blood assay for clinical evaluation of biochemical efficacy of cyclooxygenase inhibitors. Inflamm. Res. 1996, 45, 68-74.

13. Duarte, C.D.; Barreiro, E.J.; Fraga, C.A.M. Privileged Structures: A Useful Concept for the Rational Design of New Lead Drug Candidates. Mini-Rev. Med. Chem. 2007, 7, 1108-1119.

14. Evans, B.E.; Rittle, K.E.; Bock, M.G.; Dipardo, R.M.; Freidinger, R.M.; Whitter, W.L.; Lundell, G.F.; Veber, D.F.; Anderson, P.S.; Chang, R.S.L.; et al. Methods for drug discovery: Development of potent, selective, orally effective cholecystokinin antagonists. J. Med. Chem. 1988, 31, 2235-2246.

15. Rollas, S.; Küçükgüzel, S.G. Biological Activities of Hydrazone Derivatives. Molecules 2007, 12, 1910-1939.

16. Cage, J.L.; Onrust, R.; Johnston, D.; Osnowski, A.; MacDonald, W.; Mitchell, L.; Ürogdi, L.; Rohde, A.; Harbol, K.; Gragerov, S.; et al. N-Acylhydrazones as inhibitors of PDE10A. Bioorg. Med. Chem. 2011, 21, 4155-4159.

17. Tributino, J.M.L.; Duarte, C.D.; Corrêa, R.S.; Doriguetto, A.C.; Ellena, J.; Romeiro, N.C.; Castro, N.G.; Miranda, A.L.P.; Barreiro, E.J. Novel 6-methanesulfonamide-3,4methylenedioxyphenyl- $N$-acylhydrazones: Orally effective anti-inflammatory drug candidates. Bioorg. Med. Chem. 2009, 17, 1125-1131.

18. Duarte, C.D.; Tributino, J.L.M.; Lacerda, D.I.; Martins, M.V.; Alexandre Moreira, M.S.; Dutra, F.; Bechara, E.J.H.; De Paula, F.S.; Goulart, M.O.F.; Ferreira, J.; et al. Synthesis, Pharmacological evaluation and electrochemical studies of novel 6-nitro-3,4methylenedioxyphenyl- $N$-acylhydrazone derivatives: Discovery of LASSBio-881, A new ligand of cannabinoid receptors. Bioorg. Med. Chem. 2007, 15, 2421-2433. 
19. Tian, B.; He, M.; Tang, S.; Hewlett, I.; Tan, Z.; Li, J.; Jin, Y.; Yang, M. Synthesis and antiviral activities of novel acylhydrazone derivatives targeting HIV-1 capsid protein. Bioorg. Med. Chem Lett. 2009, 19, 2162-2167.

20. Diaz, P.; Phatak, S.S.; Xu, J.; Astruc-Diaz, F.; Cavasotto, C.N.; Naguib, M.J. 6-methoxy-VValkyl isatin acylhydrazone derivatives as a novel series of potent selective cannabinoid receptor 2 inverse agonists: Design, Synthesis, and binding mode prediction. Med. Chem. 2009, 52, 433-444.

21. Fraga, C.A.M.; Barreiro, E.J. Medicinal chemistry of N-acylhydrazones: New lead-compounds of analgesic, Antiinflammatory and antithrombotic drugs. Curr. Med. Chem. 2006, 13, 167-198.

22. Barreiro, E.J.; Fraga, C.A.M.; Miranda, A.L.P.; Rodrigues, C.R. A química medicinal de $\mathrm{N}$-acilidrazonas: novos compostos protótipos de fármacos analgésicos, antiinflamatórios e anti-trombóticos. Quim. Nova 2002, 25, 129-148.

23. Mahy, J.P.; Gaspard, S.; Mansuy, D. Phenylhydrazones as new good substrates for the dioxygenase and peroxydase reactions of prostaglandin synthase: Formation of Iron (III)-sigma-phenyl complexes. Biochemistry 1993, 32, 4014-4021.

24. Zia-ur-Rehman, M.; Choudary, J.A.; Elsegood, M.R.J.; Siddiqui, H.L.; Khan, K.M. A facile synthesis of novel biologically active 4-hydroxy- $N^{\prime}$-(benzylidene)-2H-benzo[e][1,2]thiazine-3carbohydrazide 1,1-dioxides. Eur. J. Med. Chem. 2009, 44, 1311-1316.

25. Ahmad, M.; Zia-ur-Rehman, M.; Siddiqui, H.L.; Ullah, M.F.; Parvez, M. Microwave assisted synthesis and structure-activity relationship of 4-hydroxy- $N^{\prime}$-[1-phenylethylidene]-2H/2-methyl1,2-benzothiazine-3-carbohydrazide 1,1-dioxides as anti-microbial agents. Eur. J. Med. Chem. 2011, 46, 2368-2377.

26. Ahmad, M.; Rizvi, S.U.F.; Siddiqui, H.L.; Ahmad, S.; Parvez, M.; Suliman, R. Antioxidant and antimicrobial studies of novel N0-(substituted-2-chloroquinolin-3-yl)methylidene-4-hydroxy-2H1,2-benzothiazine-3-carbohydrazides 1,1-dioxides. Med. Chem. Res. 2012, 21, 2340-2348.

27. Lombardino, J.G.; Wiseman, E.H.; Chianini, J. Potent Antiinflammatory N-Hetherocyclic 3-Carboxamides of 4-Hydroxi-2-methyl-2H-1,2-benzothiazine 1,1-dioxide. J. Med. Chem. 1973, 16, 493-496.

28. Wang, J.; Limburg, D.; Carter, J.; Mbalaviele, G.; Gierse, J.; Vazquez, M. Selective inducible microsomal prostaglandin E2 synthase-1 (mPGES-1) inhibitors derived from an oxicam template. Bioorg. Med. Chem. Lett. 2010, 20, 1604-1609.

29. de Leval, X.; Julémon, F.; Delarge, J.; Pirotte, B.; Dogné, J.-M. New Trends in Dual 5-LOX/COX Inhibition. Curr. Med. Chem. 2002, 9, 941-962.

30. Lombardino, J.G.; Wiseman, E.H.; McLamore, W.M. Synthesis and Antiinflammatory Activity of some 3-carboxamides of 2-alkyl-4-hydroxy-2H-1,2-benzothiazine-1,1-dioxide. J. Med. Chem. 1971, $14,1171-1175$.

31. Lima, P.C.; Lima, L.M.; Silva, K.C.P.; Leda, P.H.O.; Miranda, A.L.P.; Fraga, C.A.M.; Barreiro, E.J. Synthesis and analgesic activity of novel $N$-acylhydrazones and isosters, derived from natural safrole. Eur. J. Med. Chem. 2000, 35, 187-203.

32. Kümmerle, A.E.; Raimundo, J.M.; Leal, C.M.; da Silva, G.S.; Balliano, T.L.; Pereira, M.A.; de Simone, C.A.; Sudo, R.T.; Zapata-Sudo, G.; Fraga, C.A.M.; et al. Studies towards the identification of putative bioactive conformation of potent vasodilator arylidene $N$-acylhydrazone derivatives. Eur. J. Med. Chem. 2009, 44, 4004-4009. 
33. Cui, Z.; Li, Y.; Ling, Y.; Huang, J.; Cui, J.; Wang, J.R.; Yang, X. New class of potent antitumor acylhydrazone derivatives containing furan. Eur. J. Med. Chem. 2010, 45, 5576-5584.

34. Cunha, A.C.; Figueiredo, J.M.; Tributino, J.L.; Miranda, A.L.; Castro, H.C.; Zingali, R.B.; Fraga, C.A.; de Souza, M.C.; Ferreira, V.F.; Barreiro, E.J. Antiplatelet properties of novel N-substituted-phenyl-1,2,3-triazole-4-acylhydrazone derivatives. Bioorg. Med. Chem. 2003, 11, 2051-2059.

35. Silva, G.A.; Costa, L.M.M.; Brito, F.C.F.; Miranda, A.L.P.; Barreiro, E.J.; Fraga, C.A.M. New class of potent antinociceptive and antiplatelet $10 \mathrm{H}$-phenothiazine-1-acylhydrazone derivatives. Bioorg. Med. Chem. 2004, 12, 3149-3158.

36. Syakaev, V.V.; Podyachev, S.N.; Buzykin, B.I.; Latypov, S.K.; Habicher, W.D.; Konovalov, A.I. NMR study of conformation and isomerization of aryl- and heteroarylaldehyde 4-tertbutylphenoxyacetylhydrazones. J. Mol. Struct. 2006, 788, 55-62.

37. Silva, Y.K.C.; Augusto, C.V.; Barbosa, M.L.C.; Melo, G.M.A.; Queiroz, A.C.; Dias, T.L.M.F.; Bispo-Júnior, W.; Barreiro, E.J.; Lima, L.M.; Alexandre-Moreira, M.S. Synthesis and pharmacological evaluation of pyrazine $N$-acylhydrazone derivatives designed as novel analgesic and anti-inflammatory drug candidates. Bioorg. Med. Chem. 2010, 18, 5007-5015.

38. Palla, G.; Predieri, G.; Domiano, P.; Vignali, C.; Turner, W. Conformational behaviour and E/Z isomerization of $N$-acyl and $N$-aroylhydrazones. Tetrahedron 1986, 42, 3649-3654.

39. Farrugia, L.J. Ortep-3 for Windows-A Version of ORTEP-III with a Graphical User. J. Appl. Cryst. 1997, 30, 565-566.

40. Collier, H.O.; Dinneen, L.C.; Johnson, C.A.; Schneider, C. The abdominal constriction response and its supression by analgesic drugs in the mouse. Br. J. Pharmacol. 1968, 32, 295-310.

41. Hunskaar, S.; Hole, K. The formalin test in mice: dissociation between inflammatory pain. Pain 1987, 30, 103-114.

42. Shibata, M.; Ohkubo, T.; Takahashi, H.; Inoki, R. Modified formalin test; characteristic biphasic pain response. Pain 1989, 38, 347-352.

43. Tjolsen, A.; Berge, O.G.; Hunskaar, S.; Rosland, J.H.; Hole, K. The formalin test: an evaluation of the method. Pain 1992, 51, 15-17.

44. Woolfe, G.; MacDonald, A.D. Evaluation of analgesic action of pethidine hydrochloride (Demerol). J. Pharmacol. Exp. Ther. 1944, 80, 300-307.

45. Eddy, N.B.; Leimbach, D. Synthetic analgesics. II. Dithienylbutenylamines and dithienylbutylamines. J. Pharmacol. Exp. Ther. 1953, 107, 385-393.

46. Kuraishi, Y.; Harada, Y.; Aratani, S.; Satoh, M.; Takagi, H. Involvement of the spinal noradrenergic and serotonergic systems in morphine analgesia: The differences in mechanical and thermal algesic tests. Brain Res. 1983, 273, 245-252.

47. Le Bars, D.M.; Gozariu, M.; Cadden, S.W. Animal models of nociception. Pharmacol. Rev. 2001, 53, 597-652.

48. Doherty, N.S.; Poubelle, P.; Borgeat, P.; Beaver, T.H.; Westrich, G.L.; Schrader, N.L. Intraperitoneal injection of zymosan in mice induces pain, inflammation and the synthesis of peptidoleukotrienes and prostaglandin E2. Prostaglandins 1985, 30, 769-789.

49. Leite, D.F.P.; Echevarria-Lima, J.; Ferreira, S.C.; Calixto, J.B.; Rumjanek, V.M.J. ABCC transporter inhibition reduces zymosan-induced peritonitis. Leuk. Biol. 2007, 82, 630-637. 
50. Ferrándiz, M.L.; Alcaraz, M.J. Antiinflammatory activity and inhibition of arachidonic acidmetabolism by flavonoids. Inflamm. Res. 1991, 32, 283-288.

51. Glaser, K.; Sung, M.-L.; O’Neill K; Belfast, M.; Hartman, D.; Carlson, R.; Kreft, A.; Kubrak, D.; Hsiao, C.-L.; Weichman, B. Etodolac selectively inhibits human prostaglandin G/H synthase 2 (PGHS-2) versus human PGHS-1. Eur. J. Pharmacol. 1995, 281, 107-111.

52. Sheldrick, G.M. A short history of SHELX. Acta Cryst. 2008, 64, 112-122.

53. Farrugia, L.J. WinGX Suite for Single Crystal Small Molecule Crystallography. J. Appl. Cryst. 1999, 32, 837-838.

Sample Availability: Samples of the compounds 14a-h are available from the authors.

(C) 2012 by the authors; licensee MDPI, Basel, Switzerland. This article is an open access article distributed under the terms and conditions of the Creative Commons Attribution license (http://creativecommons.org/licenses/by/3.0/). 